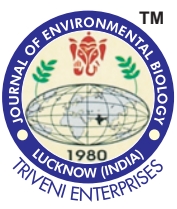

\title{
Fecundity of Acanthomysis koreana at surf zone in Kkotji beach on the west coast of Korea
}

\section{Authors Info \\ J.H. Kim', J.H. Choi', H.S. Han and C.W. $\mathrm{Ma}^{3 *}$ \\ ${ }^{1}$ Fisheries Resources Research Center, National Institute of Fisheries Science, \\ Tongyeong, 53064, Korea \\ ${ }^{2}$ Korea Environment Corporation, Incheon, 22619, Korea \\ ${ }^{3}$ Department of Life Science and Biotechnology, Soonchunhyang University, Asan, 31538, \\ South Korea}

*Corresponding Author Email : cwooma@sch.ac.kr

\section{Edited by}

Professor Wongyu Park

\section{Reviewed by}

Dr. Seong Yong Moon

Dr. Jung Nyun Kim

\section{Abstract}

Aim: The present investigation was carried out to study seasonal changes in the habitat of Acanthomysis koreana that inhabits the surf zone of Kkotji beach in the west coast of Korean peninsula together with the changes in their fecundity associated with respective sizes of individuals and (most) influential factors affecting the fecundity.

Methodology: Sampling was done during June 2014 - May 2015 with the help of a 50-100 cm depth of the surf zone of Kkotji beach at the time of spring tide.

Results: During November to December, 2014, a seasonal change in water temperature was observed wherein the biggest difference in water temperature marked approximately $9^{\circ} \mathrm{C}$. The annual level of salinity in the subject area of investigation varied insignificantly. The number of eggs observed therein recorded the highest level in spring and the lowest level in summer. The brooded eggs were higher in spring than summer. The number of eggs in each season exhibited positive correlation with the increasing length of carapace of brooding females. However, the size of eggs in each season showed no significant differences.

Interpretation: Fecundity of Acanthomysis koreana was found higher in spring than in autumn.

Key words: Acanthomysis koreana, Fecundity, Kkotji beach, Life cycle, Salinity

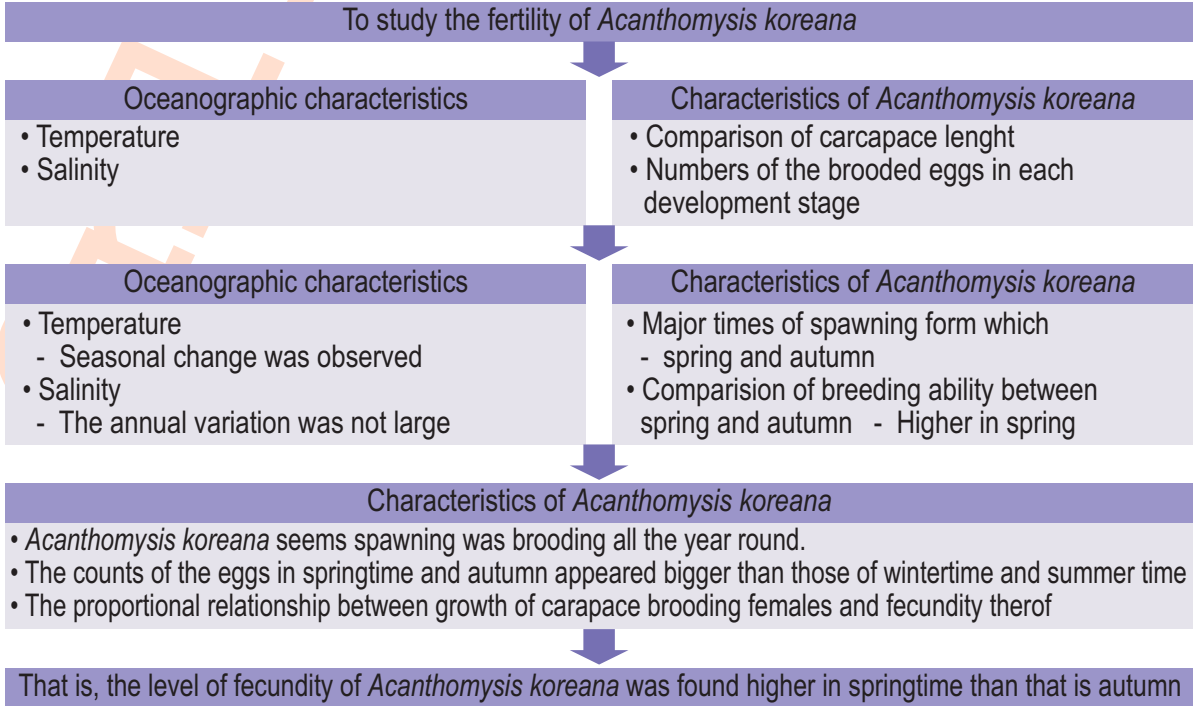

How to cite : Kim, J.H., J.H. Choi, H.S. Han and C.W. Ma: Fecundity of Acanthomysis koreana at surf zone in Kkotji beach on the west coast of Korea. J. Environ. Biol., 40, 908-916 (2019). DOI : http://doi.org/10.22438/jeb/40/5(SI)/SI-11 


\section{Introduction}

Mysidae is a family of epibenthic zooplankton that mainly inhabits estuaries, inland seas, and shallow seas of back bays (Ma, 1996). Zooplankton are feed for small fishes and mediumsized crustaceans, and are benthic planktons playing the intermediate level of ecosystems in estuaries and nearshore waters (Hong et al., 1989). Thus, a degree of blooming of mysidae is an important factor determining the balance and health of ecosystems in estuaries and nearshore waters.

Breeding characteristics of crustaceans such as time and period of breeding etc., is known to be determinant over blooming of its population (Schneider and Harrington, 1981; Mccurdy et al., 2005). Fecundity was studied to analyze the ecological characteristics such as behavior of population and life cycle of Mysidae. The period of brooding and number of eggs contained in brood pouch have been used to determine the fecundity (Mauchline, 1965; Delgado et al., 2013). Archaeomysis kokuboi is a mysid shrimp that inhabitats nearshore waters in the southern coast of Korean peninsula, It has highest level of fecundity during spring (Ma, 2001). Han (2013) reported that in Archaeomysis vulgaris, the breeding power of the females grew with increasing growth. Besides, the seasonal changes in the habitat of Mysidae that inhabit nearshore waters have been known that the changed habitat affects the growth of individuals (Ma, 1996; Mauchline, 1980; Turpen et al., 1994); this has necessitated the clarification of characteristics of fecundity associated with the habitat and size of individuals.

In view of the above, this study was carried out to investigate the seasonal changes in the habitat of Acanthomysis koreana in the tidal flat of west coast, and to investigate the environmental factors affecting the breeding ability.

\section{Materials and Methods}

Sampling of Acanthomysis koreana was carried from June 2014 to May 2015, with the help of a sledge net $(330 \mu \mathrm{m}$ mesh, W; $40 \mathrm{~cm}, \mathrm{H} ; 35 \mathrm{~cm}$ ) (Fig. 1) at 50-100 cm depth of the surf zone of Kkotji beach (Fig. 2) during spring tide. The sampled individuals of Acanthomysis koreana were visually inspected and then fixed in 5\% neutral formalin; and the female individuals were distinguished by checking the presence of brood pouch. Water temperature and salinity were estimated with a portable water quality measuring instrument(YSI-556MPS).

The length of carapace of female Acanthomysis koreana were taken with the precision of micrometers with an image analyzing program (ImageJ java 1.8.0_77)(Fig. 3). Four seasons of the habitat were distinguished by water temperature: summerwater temperature over $20^{\circ} \mathrm{C}$, winter-water temperature below $10^{\circ} \mathrm{C}$, and spring and autumn - water temperature ranging from $10^{\circ} \mathrm{C}-20^{\circ} \mathrm{C}$. Generations of Acanthomysis koreana were distinguished by each season; the numbers of eggs from each generation were compared with each other from which, the major spawning period that corresponded to relatively largest number of eggs was estimated.

The developmental stages of eggs in brood pouch were distinguished into three stages by counting the eggs separated from brood pouch and transferred to Petri dish under dissecting microscope (Olympus-SZ51).

The distinguished three stages comprised the following: the embryonic stage of smooth spherical shape of the eggs, the nauplioid stage of the manifestation of abdominal part with an appearance of telson, and the postnauplioid stage distinguished by the appearance of eye spot. The size of egg was measured (in $\mathrm{mm}$ ) as diameter of the longest part of egg (embryonic stage) and

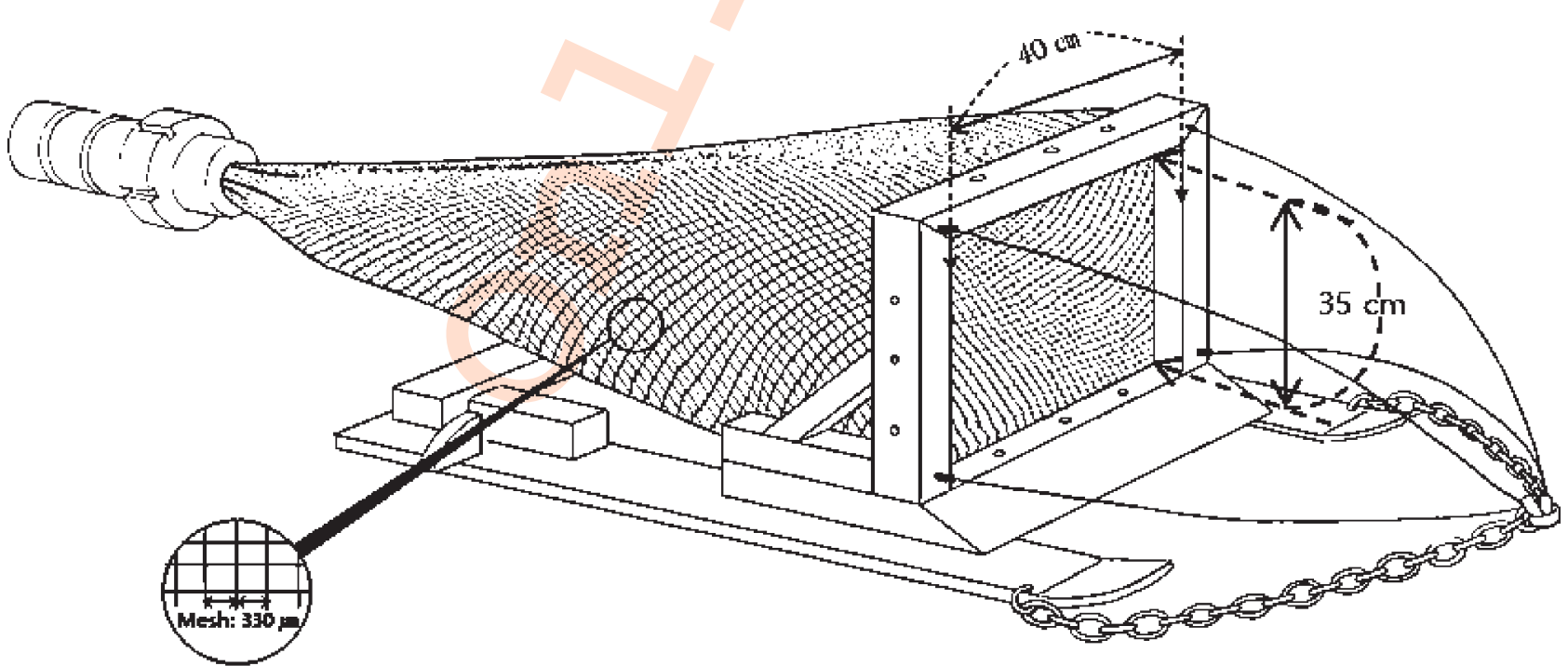

Fig. 1 : Sampling gear (sledge net) used to collect Acanthomysis koreana in Kkotji beach on the western coast of Korea. 


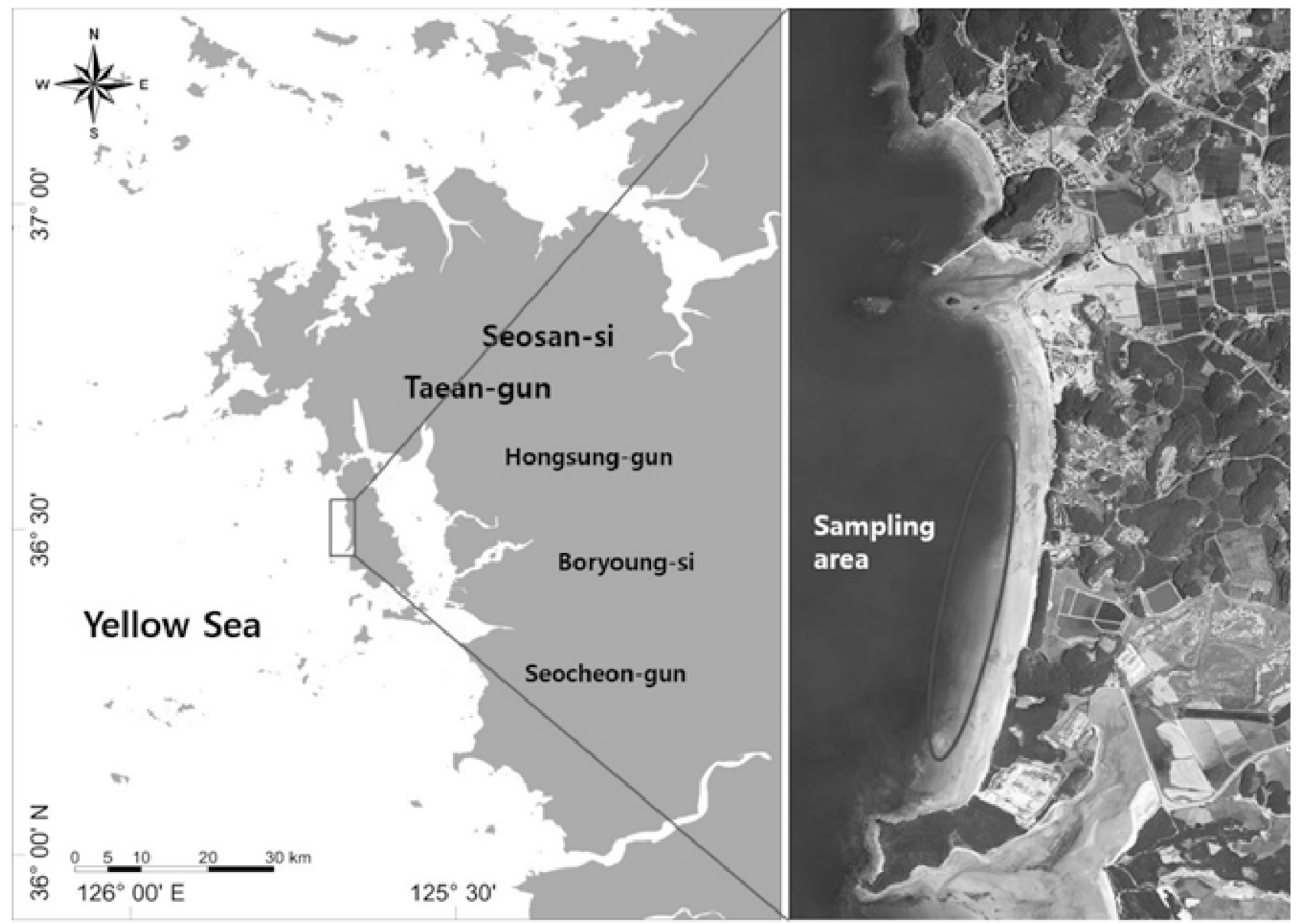

Fig. 2 : The sampling site of Acanthomysis koreana in Kkotji beach on the west coast of Korea.

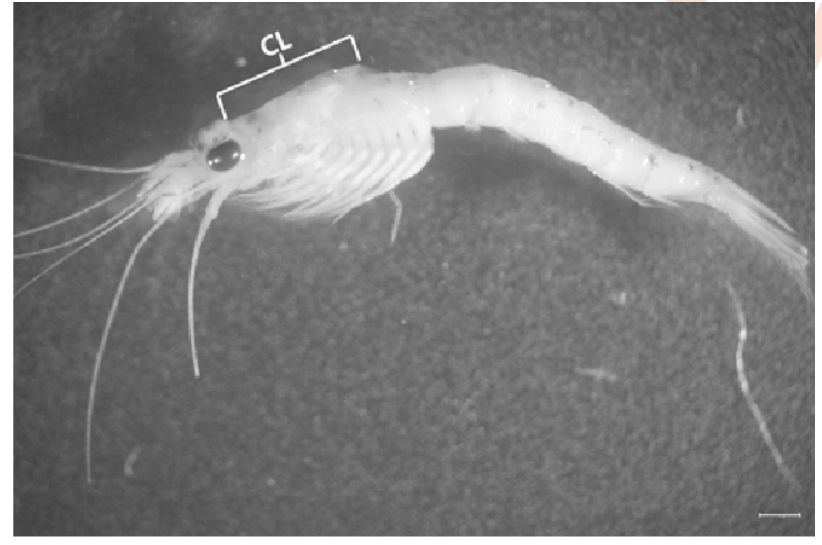

Fig. 3 : Measurement part of Acanthomysis koreana (CL: carapace length scale bar: $1 \mathrm{~mm}$ ).

the entire length (postnauplioid stage) with image analysis program (ImageJ java 1.8.0_77) (Fig. 4).

The correlation between developmental stage and counts of brooded eggs, and the statistical significance of collected data were tested through the statistical packages of IBM SPSS (ver. 22) and Sigma plot (ver. 12.5).

\section{Results and Discussion}

Water temperature of the sampling area of Acanthomysis koreana ranged from $5.24^{\circ} \mathrm{C}$ to $25.22^{\circ} \mathrm{C}$, the highest and lowest temperatures were recorded in July 2017 and January 2015. The seasonal variations in water temperature ranged from $13.32 \pm$ $2.95^{\circ} \mathrm{C}$ (spring), $23.81 \pm 1.52^{\circ} \mathrm{C}$ (summer), $17.53 \pm 2.35^{\circ} \mathrm{C}$ (autumn) and $5.58 \pm 0.25^{\circ} \mathrm{C}$ (winter); the highest range of fluctuation of water temperature was approximately $9^{\circ} \mathrm{C}$ that occurred during November to December.

Water salinity ranged between 30.12-32.24 psu; the lowest level of salinity was noted in August 2014 whereas the highest salinity was observed from July 2014 to February 2015 (Fig. 5). Seasonal variations in salinity level was $32.11 \pm 0.01 \mathrm{psu}$ (spring), $30.23 \pm 0.11 \mathrm{psu}$ (summer), $31.21 \pm 0.01 \mathrm{psu}$ (autumn) and $31.15 \pm 0.87 \mathrm{psu}$ (winter); the annual variation in salt content in the subject area of investigation was found insignificant. 

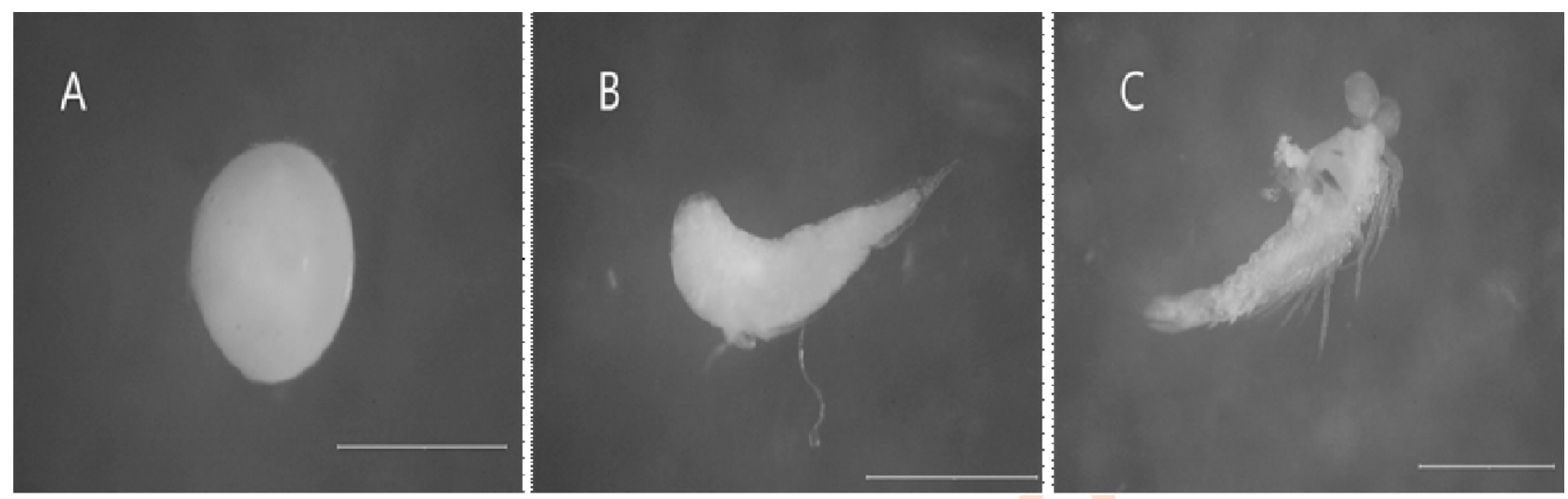

Fig. 4 : Developmental stages of Acanthomysis koreana egg (A: embryonic stage, B: nauplioid stage, C: postnauplioid stage, scale bars: $1 \mathrm{~mm}$ ).

30

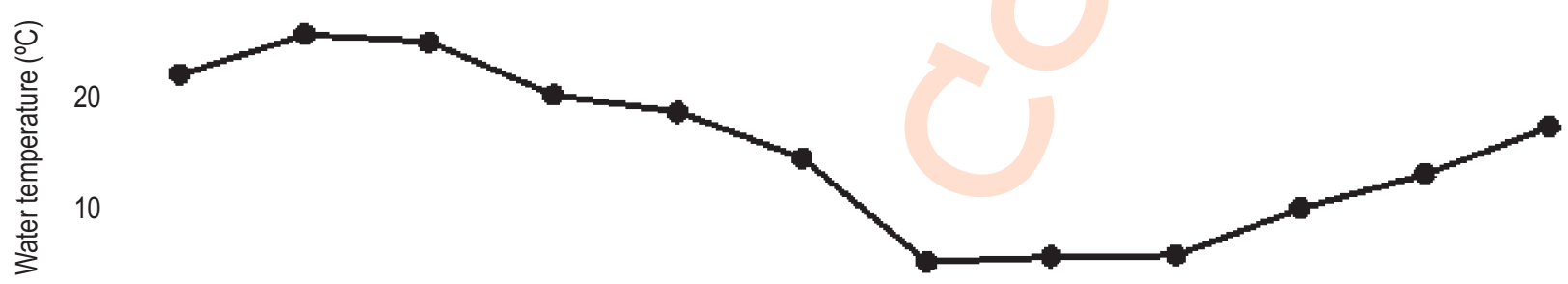

0

35

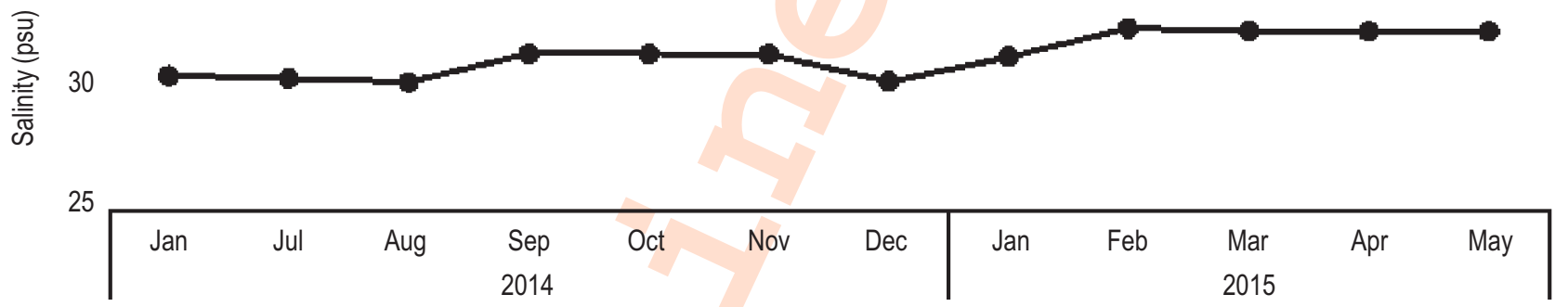

Fig. 5 : Monthly variation of water temperature and salinity in the surf zone at Kkoji beach from Jun 2014 to May 2015 on the western coast of Korea.

The appearance of eggs at each developmental stage of Acanthomysis koreana are as follows: $36.43 \%$ embryonic stage, $34.90 \%$ nauplioid stage, and $28.67 \%$ postnauplioid stage; the embryonic stage was dominant and appeared in every season, except January 2015. With respect to the appearance of developmental stages of eggs, the nauplioid stage marked the lowest and highest appearances in both summer and winter whereas the post nauplioid stage marked the highest and lowest appearances in both summer and winter; the embryonic stage appeared all the year round without significant variations. Thus, in Acanthomysis koreanas pawning and brooding occurred all the year round.

The average number of brooded eggs of Gastrosaccus Iobatus, G. psammodytes, G. spiniferand Archaeomysis vulgaris, which inhabit the areas similar to that of sampling area of
Acanthomysis koreana in the present study, ranged from 20 to 60 . These results are in confirmation with the previous reports (Macquart-Moulin, 1965; Brown and Talbot, 1972; Mauchline, 1972; Han, 2013). However, the average number of brooded eggs of $A$. thailandica, which belongs to same genus of Acanthomysis koreana and inhabits the sea area of Melaka, Malaysia, ranged from 53 to 147, showing significant difference from the results obtained in the present study (Ramarn et al., 2012).

Reported that difference in water temperature differ at different latitudes directly determines the time of spawning and number of brooded eggs in mysidae (Mauchline, 1980; Toda et al,. 1984; Bea, 2015). Thus, the difference in number of brooded eggs above seems attributable to higher water temperature $\left(26.47-31.09^{\circ} \mathrm{C}\right)$ of the equatorial zone wherein $A$. thailandica 


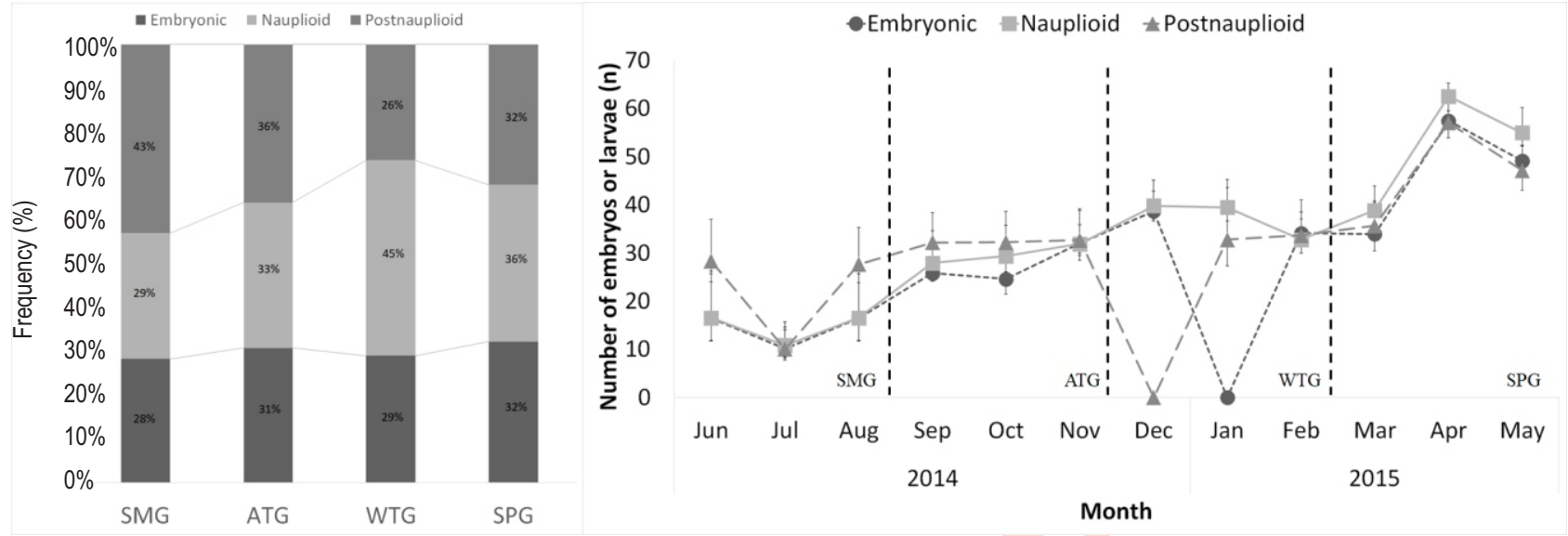

Fig. 6 : Seasonal variation of three developmental stages of embryos and larvae in Acanthomysis koreana in Kkotji beach from June 2014 to May 2015 on the western coast of Korea (SMG: Summer generation, ATG: Autumn generation, WTG: Winter generation, SPG: Spring generation).

Table 1 : Monthly and seasonal mean of number of embryos or larvae of Acanthomysis koreana in Kkotji beach from June 2014 to May 2015 on the western coast of Korea

\begin{tabular}{|c|c|c|c|c|c|c|c|c|c|}
\hline & \multicolumn{2}{|c|}{ MonthlStage } & \multirow[t]{2}{*}{ Embryonic } & \multirow[t]{2}{*}{ Nauplioid } & \multirow[t]{2}{*}{ Postnauplioid } & \multicolumn{3}{|c|}{ Season } & \multirow[b]{2}{*}{ Spring } \\
\hline & & & & & & Summer & Autumn & Winter & \\
\hline \multirow{24}{*}{$\begin{array}{l}\text { Number } \\
\text { of embryos } \\
\text { and larvae }\end{array}$} & \multirow{2}{*}{ Jun } & Mean & 16.50 & 16.56 & 28.31 & \multirow{26}{*}{$\begin{array}{l}17.02 \\
( \pm 6.45)\end{array}$} & & & \\
\hline & & $\mathrm{SD}( \pm)$ & 9.21 & 9.72 & 8.61 & & & & \\
\hline & \multirow[t]{2}{*}{ Jul } & Mean & 10.2 & 10.84 & 10.08 & & & & \\
\hline & & $\mathrm{SD}( \pm)$ & 3.89 & 4.92 & 4.52 & & & & \\
\hline & \multirow[t]{2}{*}{ Aug } & Mean & 16.50 & 16.56 & 27.67 & & & & \\
\hline & & $\mathrm{SD}( \pm)$ & 9.21 & 9.72 & 7.64 & & & & \\
\hline & \multirow[t]{2}{*}{ Sep } & Mean & 25.85 & 27.93 & 32.17 & & 29.87 & & \\
\hline & & $\mathrm{SD}( \pm)$ & 3.39 & 6.72 & 6.28 & & $( \pm 2.89)$ & & \\
\hline & \multirow[t]{2}{*}{ Oct } & Mean & 24.62 & 29.36 & 32.26 & & & & \\
\hline & & $\mathrm{SD}( \pm)$ & 6.37 & 6.35 & 6.33 & & & & \\
\hline & \multirow[t]{2}{*}{ Nov } & Mean & 32 & 31.90 & 32.70 & & & & \\
\hline & & $\mathrm{SD}( \pm)$ & 3.90 & 6.90 & 6.51 & & & & \\
\hline & \multirow[t]{2}{*}{ Dec } & Mean & 38.70 & 39.80 & 0 & & & 27.94 & \\
\hline & & $\mathrm{SD}( \pm)$ & 4.19 & 5.34 & 0 & & & $( \pm 15.17)$ & \\
\hline & \multirow[t]{2}{*}{ Jan } & Mean & 0 & 39.50 & 32.80 & & & & \\
\hline & & $\mathrm{SD}( \pm)$ & 0 & 5.77 & 10.83 & & & & \\
\hline & \multirow[t]{2}{*}{ Feb } & Mean & 34.14 & 32.81 & 33.67 & & & & \\
\hline & & $\mathrm{SD}( \pm)$ & 2.90 & 5.66 & 7.44 & & & & \\
\hline & \multirow[t]{2}{*}{ Mar } & Mean & 33.94 & 38.88 & 35.69 & & & & 48.55 \\
\hline & & $\mathrm{SD}( \pm)$ & 6.96 & 5.07 & 4.79 & & & & $( \pm 9.80)$ \\
\hline & \multirow[t]{2}{*}{ Apr } & Mean & 57.45 & 62.57 & 57.08 & & & & \\
\hline & & $\mathrm{SD}( \pm)$ & 2.06 & 2.77 & 6.33 & & & & \\
\hline & \multirow[t]{2}{*}{ May } & Mean & 49.19 & 55 & 47.17 & & & & \\
\hline & & $\mathrm{SD}( \pm)$ & 3.03 & 5.26 & 8.30 & & & & \\
\hline \multirow[t]{2}{*}{ Total } & & Mean & 28.26 & 33.48 & 30.80 & & & & \\
\hline & & $\mathrm{SD}( \pm)$ & 7.77 & 7.29 & 7.07 & & & & \\
\hline
\end{tabular}

inhabits water temperature in the mid-latitude zone of Acanthomysis koreana $\left(5.24-25.22^{\circ} \mathrm{C}\right)$.

The number of brooded eggs at each developmental stage, during eaeh season, were counted to determine the major spawning period. It was found that the number of eggs during spring and autumn was highest as compored to winter and summer. Spring and autumn were, thus, as major spawning period (Spearman's correlation, R2 =0.67, $p<0.05)$ (Fig. 6, Table 1). 


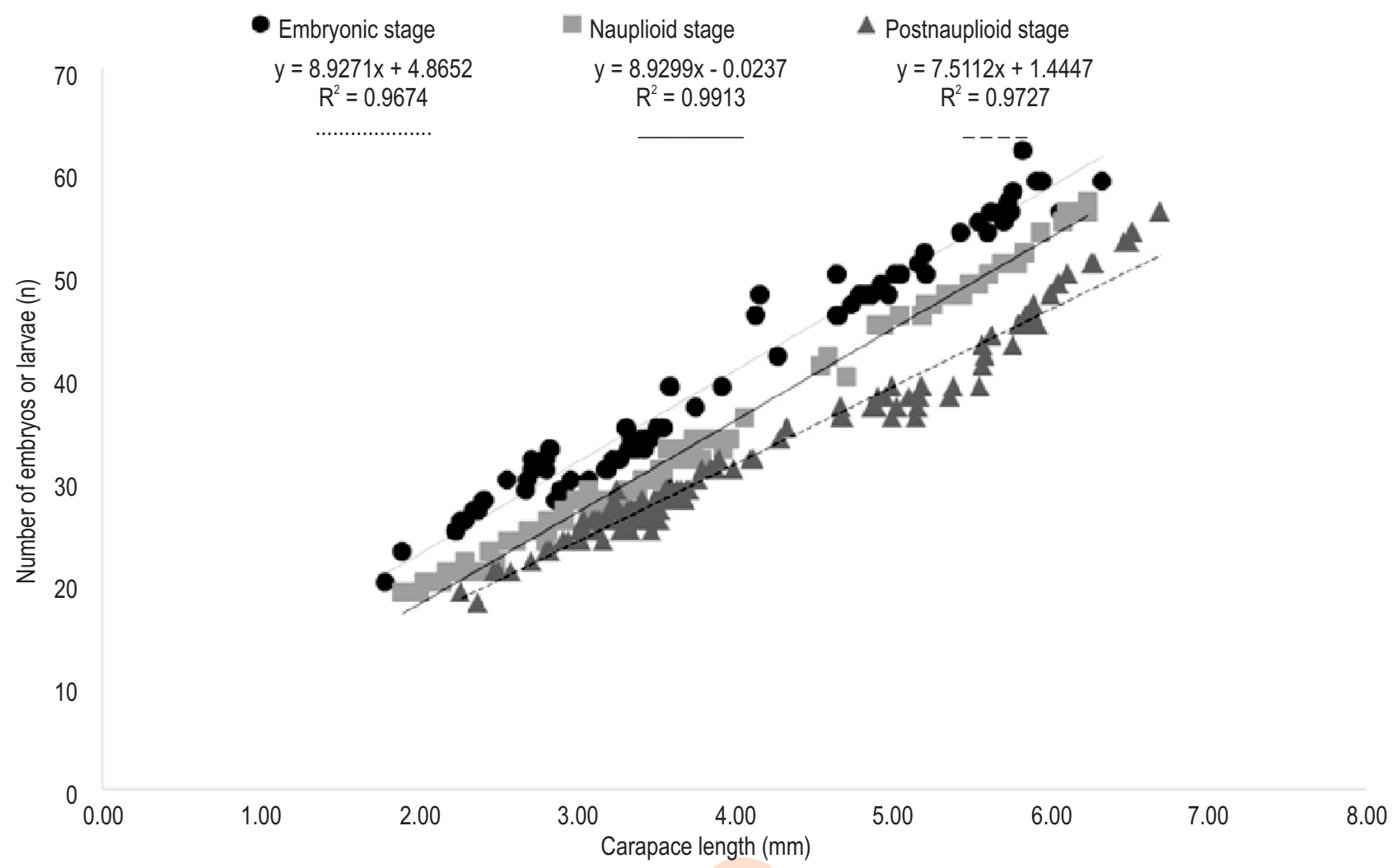

Fig. 7 : Relationship between number of embryos or larvae and carapace length of Acanthomysis koreana to different developmental stages.

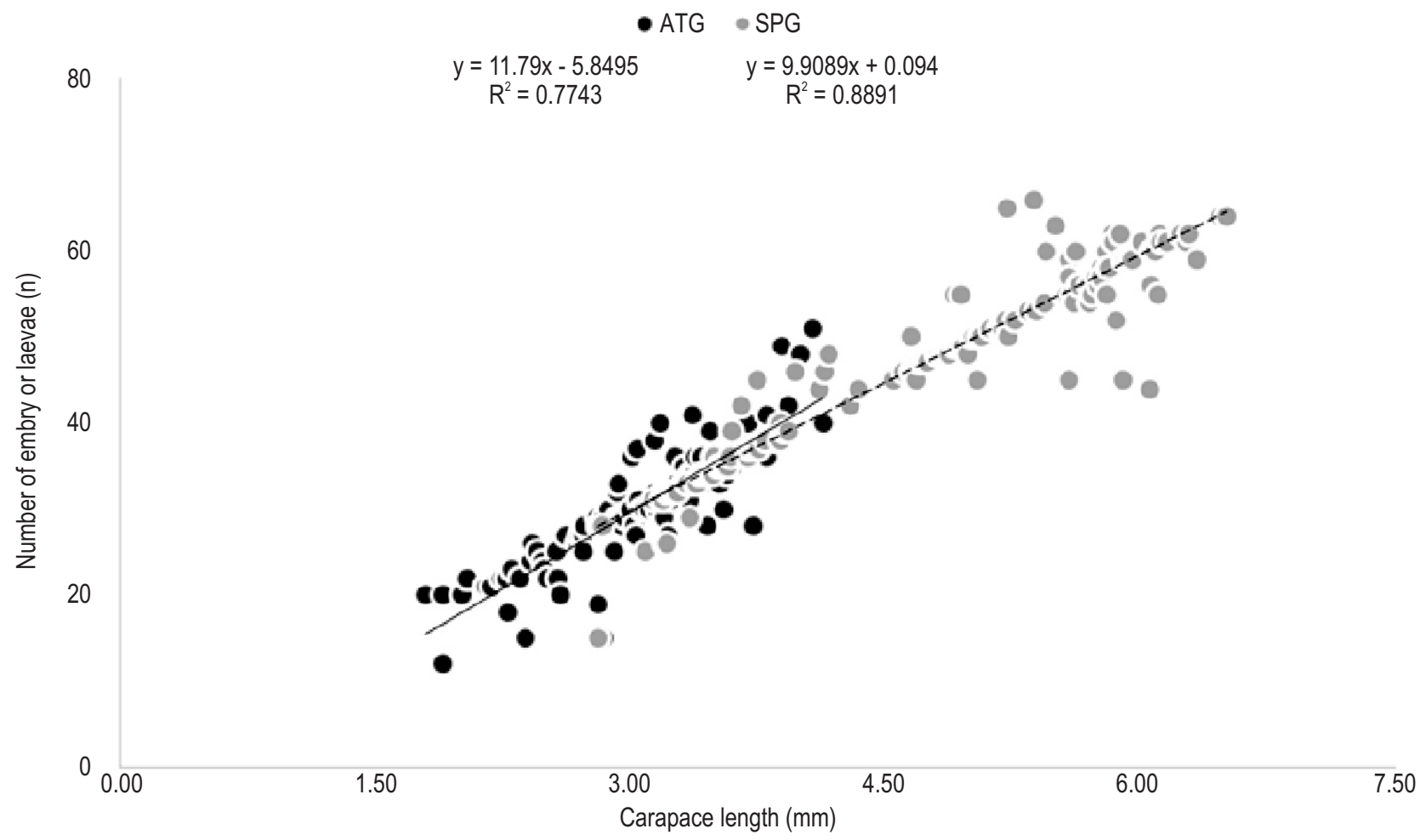

Fig. 8 : Relationship between number of embryos or larvae and carapace length of Acanthomysis koreana to different generations (ATG: Autumn generation, SPG: Spring generation). 


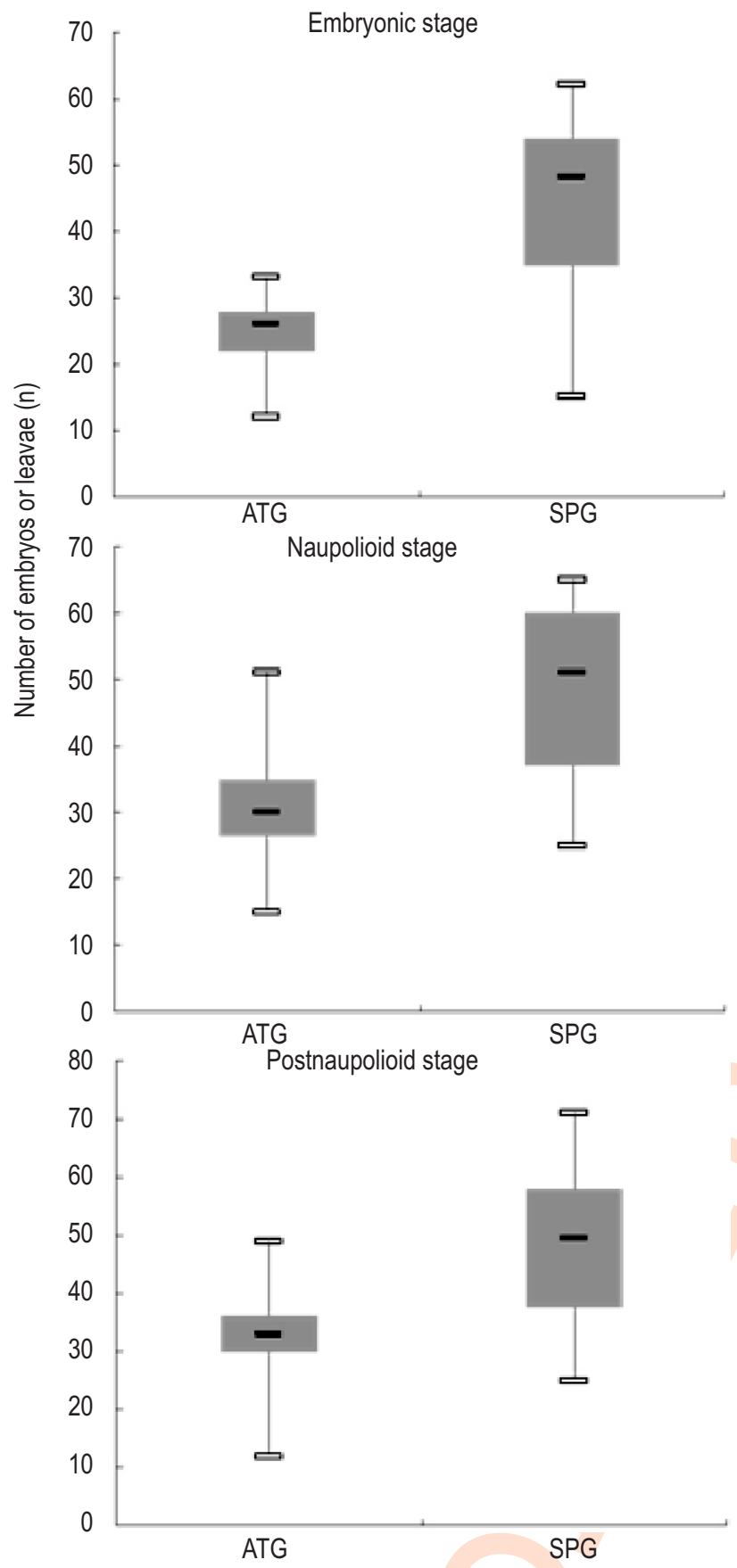

Fig. 9 : Comparison of number of embryos or larvae in different generations of Acanthomysis koreana. The error bar is standard deviation (ATG: Autumn generation, SPG: Spring generation).

Fecundity of animals at lower trophic level in marine ecosystem is highly affected by their feeds (Murtaugh, 1989). Turpen et al. (1994) reported the changes in source of feeds due to varied water temperature as one of the major factors causing seasonal changes in fecundity of Mysidae in their study on Holmesimysis coastata. The surf zone of Kkotji beach wherein
Acanthomysis koreana inhabits, the subject species of the present study, showed typical marine environment of temperate sea area wherein the water temperature raised in spring, reached peak during summer, and lowered in autumn. Blooming of phytoplankton has been reported to rise with water temperature during spring (Park, 2008; Yi, 2005). High count of brooded eggs in spring, identified in the present study, was associated with increased supply of feeds owing to blooming of phytoplankton; the result of the previous study on selfsame that Archaeomysis kokuboi (Ma, 2001). Han (2013) also reported the highest level of fecundity in Archaeomysis vulgaris occurred during spring to summer.

Correlation between carapace length of brooding females and egg count was analyzed to identify changes in the fecundity varying in accordance with the growth of carapace, length of brooding females in springtime and autumn, the major spawning period of Acanthomysis koreana.

A positive correlation was found (Pearson's correlation; $R 2=0.843 ; p<0.05)$ between growth of carapace of brooding females and fecundity. The carapace length of brooding females of Acanthomysis koreana at embryonic stage, nauplioid stage, and post nauplioid stage also showed positive correlation with respective egg count at each stage (Pearson's correlation; $R^{2}=$ 0.967; $\left.p<0.05, R^{2}=0.913 ; p<0.05, R^{2}=0.972 ; p<0.05\right)$. Besides, under identical carapace, the length brooding females, embryonic stage recorded the highest egg count whereas the postnauplioid stage marked the smallest egg count (Fig. 7).

The studies on fecundity of Mysidopsis bigelowi, Archaeomysis kokuboi and Archaeomysis vugaris reported the number of brooded eggs under identical carapace length decreased with progress of developmental stage of eggs. Further, the number of eggs under identical carapace length appeared lower at nauplioid stage and postnauplioid stage (Allen, 1984; Ma, 1996; Han, 2013). Therefore, correlation between the number of eggs and carapace length at each developmental stage of Acanthomysis koreana was identical to those reported from previous studies (Ramarn et al., 2012; Han, 2013; Bea, 2015).

The number of eggs at each developmental stage corresponding to carapace length of brooding females were compared with each other to identify the characteristics of fecundity in major spawning period of springtime and autumn in Acanthomysis koreana. The number of eggs appeared increasing in accordance with increasing carapace length (Spearman's correlation, $R^{2}=0.858, p<0.05$ ) and during spring and autumn (Spearman's correlation, $R^{2}=0.652, p<0.05$ ) (Fig. 8). Besides, each developmental stage of eggs commonly exhibited identical aspects wherein the level of fecundity in Acanthomysis koreana was found higher in spring than in autumn (Fig. 9). 


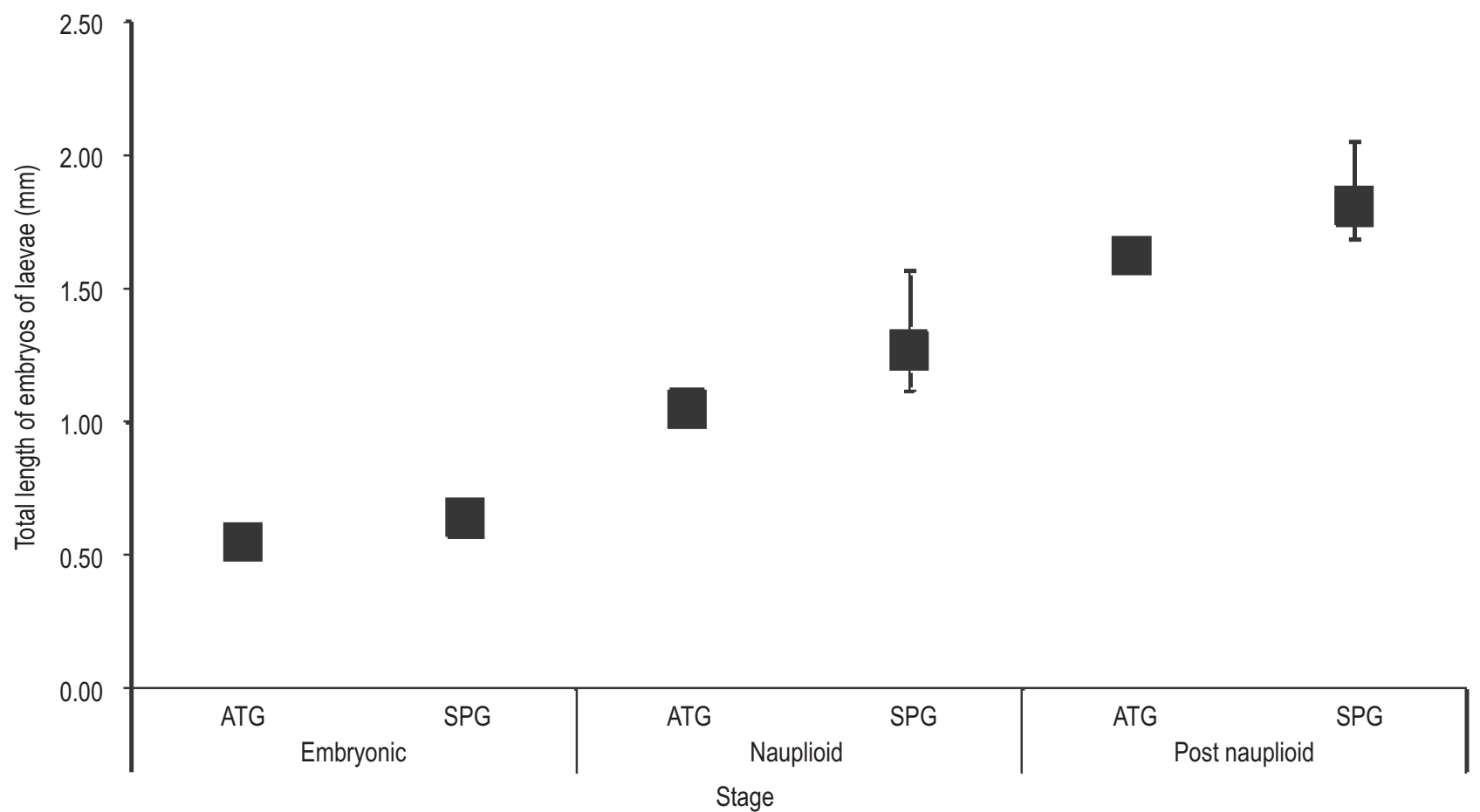

Fig. 10 : Comparison of total length of embryos or larvae in different generations of Acanthomysis koreana. The error bar is standard deviation. (ATG: Autumn generation, SPG: Spring generation).

The size of brooded eggs of Acanthomysis koreana at each developmental stage was measured to determine the difference in size of eggs spawned during main spawning period. The diameter of brooded eggs at each stage was as follows: 0.54 $\pm 0.03 \mathrm{~mm}$ at embryonic stage, $1.05 \pm 0.02 \mathrm{~mm}$ at nauplioid stage and $1.62 \pm 0.06 \mathrm{~mm}$ at post nauplioid stage. The diameter of eggs at each stage appeared to increase as the eggs underwent respective developmental stages (Pearson's correlation; $R^{2}=$ $0.868 ; p<0.05)$; no significant differences in the size of eggs were observed between spring time and autumn period (T-test, $\mathrm{t}=2.132, \mathrm{p}<0.05)($ Fig 10).

The size of eggs in developmental stages of each generation of Mysidae that inhabits temperate sea areas was reported to vary according to changing seasonal water temperature thereof (Mauchline, 1980). According to studies on the growth and fecundity of G. psammodytes conducted by Brown and Talbot (1972); on G. spinifer that inhabited northern part of the United Kingdom; and on the Archaeomysis kokuboi that inhabits the southern coast of Korean peninsula; the positive correlation of size of egg in each developmental stage with the carapace length has been known together with the differences in sizes of the eggs in developmental stages of each generation (Mauchline, 1972; Ma, 1996). However, in the previous studies conducted by Ramarn et al. (2012) and Han (2013), the difference in size of eggs spawned in the major spawning times appeared insignificant. In the present study, the size of eggs at each developmental stage which were spawned in springtime and autumn also appeared with insignificant differences from each other. Mauchline (1980) reported that correlation between length of brooding females and size of eggs would be difficult to identify species whose body length is less than $10 \mathrm{~mm}$ despite the presence of diverse relations in between. Thus, the results might be attributable to interspecies and inter-environmental differences corresponding to different latitudes. However, future studies, to be organized with schemes of identical sampling and fixation to focus on the analysis of growth of eggs in each temperature interval, seem necessary to clarify accurate cause of making absolute comparisons.

\section{References}

Allen, D.M.: Population dynamics of mysid shrimp Mysidopsis bigelowi Tattersall W. M. in a temperate estuary. J. Crust. Biol., 4, 25-34 (1984).

Bea, J.Y.: Population structure and life history of Neomysis awatschensis (Brandt, 1851) (Crustacea: Mysidae) in Jeju Island, Korea. Pukyong. Univ. Korea (2015).

Brown, A.C. and M.S. Talbot: The ecology of sandy beaches of the Cape Peninsula, South Africa Part 3. A study of Gastrosaccus psammodytes Tattersall (Crustacea: Mysidacea). T. Roy. Soc. S. Afr., 40, 309-333 (1972).

Delgado, L., G. Guerao, C. San. Vicente and C. Ribera: Population structure and life history of Hemimysis lamornae mediterranea (Malacostraca: Mysida) 32 in the Ebro Delta (NW Mediterranean). J. Sea Res., 83, 139-145 (2013). 
Han, H.S.: Population of Archaeomysis vulgaris in Hakampo beach on the west coast of Korea. Soonchunhyang Univ. Asan. Korea (2013).

Hong, S. Y. and C. W. Oh: Ecology of sand shrimp, Crangon affinis in the Nakdong River Estuary, Korea. Bull. Korean Fish. Soc., 22, 351362 (1989).

Ma, C.W.: Life history and ecology of Archaeomysis kokuboi in Songjeong Beach, Korea. Natl. Fish. Univ. Pusan Korea (1996)

Ma, C.W.: Population structure and generation analysis of Archaeomysis kokuboi (Crustacea: Mysidacea). Soonchunhyang J. Nat. Sci., 7 , 153-162 (2001).

Macquart-Moulin, C.: Les mysidacesbentho-planktoniques du Golfe de Marsrille. Redueille des Trazaux de la Station Marine d'Endoume, Faculte des Sciences de Marseille, 38, 129-253 (1965).

Mauchline, J.: Breeding and fecundity of Praunus inermis (Crustacea: Mysidacea). J. Mar. Biol. Assoc. UK, 45, 663-671 (1965).

Mauchline, J.: The biology of bathypelagic organisms, especially Crustacea. Deep-sea Res., 19, 753-780 (1972).

Mauchline, J.: The Biology of Mysids and Euaphausiids. In: Advances in Marine Biology (Eds.: J.H.S. Blaxter, F.S. Russel and M. Yonge). Vol. 18, Academic Press, U.S.A. (1980).

Mccurdy, D.G., M.R. Forbes, S.P. Logan, D. Lancaster and S.I. Mautner: Foraging and impacts by benthic fish on the intertidal amphipod
Corophium volutator. J. Crust. Biol., 25, 558-564 (2005).

Murtaugh, P.A.: Fecundity of Neomysis mecedis Holmes on lake Washington (Mysidacea). Crustaceana, 57, 194-200 (1989).

Park, C., D. B. Lee, C. R. Lee, S. R. Yang and B. G. Jung.: Variation in planktonic assemblages in Asan Bay during the winter-spring bloom. Korean Soc. Oceanograp., 4, 308-319 (2008).

Ramarn, T., V.C. Chong and H. Yukio: Population structure and reproduction of the mysid shrimp Acanthomysis thailandica (Crustacea: Mysidae) in a tropical mangrove estuary, Malaysia. Zool. Stud., 51, 768-782 (2012).

Schneider, D.C. and B.A. Harrington: Timing of shore bird migration in relation to prey depletion. The Auk, USA(1918).

Toda, H., M. Takahashi and S. Ichimura: The effect of temperature on the post-embryonic growth of Neomysis intermedia Czernlawsky (Crustacea, Mysidacea) under laboratory conditions. J. Plankton Res., 6, 647-660 (1984).

Turpen, S., J.W. Hunt, B.S. Anderson and J.S. Pearse: Population structure, growth and fecundity of the kelp forest mysid Holmesimysis coastata in Monterey, California. J. Crust. Biol., 14, 657-664 (1994).

Yi, S.H., Y.S. Sin, S.R. Yang and C. Park.: Seasonal characteristcs of phytoplankton distribution in Asan Bay. Ocean Polar Res., 27, 149159 (2005). 